\title{
Discontinuation of Dopamine Agonists in Parkinson's Disease: A Retrospective Analysis
}

\author{
Parkinson Hastalı̆̆’nda Dopamin Agonistlerinin Kesilmesi: Retrospektif BirAnaliz
}

${ }^{1}$ Fazma Nazli Durmaz, ${ }^{2}$ Muge Kuzu, ${ }^{1}$ Ozlem Aykac, ${ }^{1}$ Serhat Ozkan

${ }^{1}$ Department of Neurology, Eskișehir OsmangaziUniversity Faculty of Medicine, Eskisehir, Turkey

${ }^{2}$ Department of Neurology, LokmanHekim University Faculty of Medicine, Ankara, Turkey

Correspondence:

Fatma Nazlı DURMAZ

Department of Neurology, Eskişehir

Osmangazi UniversityFaculty of

Medicine,.Eskisehir, Turkey

e-mail:doktornazli@hotmail.com

\section{Abstract}

The most significant difficulty in dopamine agonist (DA) treatment is its adverse effects which may outweigh its efficacy or even be disabling leading to discontinuation. Limited data is available to provide a head-to-head comparison of the discontinuation rates for DAs. We aimed to investigate the prevalence and characteristics of the discontinuation of pramipexole and ropinirole treatments and to determine the risk factors related to their discontinuation in patients with Parkinson's disease (PD). The data of 329 patients that underwent DA treatment (pramipexole or ropinirole) were retrospectively determined. Demographics, disease duration, levodopa equivalent dose, dopamine agonist dosage, related adverse effects, duration of DA treatment, and the Hoehn and Yahr (HY) scale scores were compared between the two DA groups. The rate of discontinuation of the DAs due to adverse effects was $51.6 \%$. Psychiatric side effects (14.3\%) were the most common reason for discontinuation, and impulse control disorders (ICD) and pedal edema were the other prominent reasons. The discontinuation rate was higher among the patients with HY stage 2 and 3 in the pramipexole group, increased age at onset, and increased disease duration. In the ropinirole group, ICD had higher prevalence. The odds ratio of the ICD risk was found to be 2.58 times higher in the ropinirole group. Common side effects such as daytime sleepiness, constipation, and headache were not found to be reasons for the discontinuation of DAs; rather, the patients mostly discontinued these treatments due to psychosis, impulse control disorder, and pedal edema. It is noteworthy that adverse effects led to the discontinuation of treatment in over half of the patients. Further prospective randomized controlled studies on the reasons for DA discontinuation and related risk factors will be beneficial.

Keywords: Discontinuation, dopamine agonists, Parkinson's disease, adverse effect

\section{Özet}

Parkinson hastalığında dopamin agonisti (DA) tedavisindeki en önemli zorluk, etkisinden daha ağır basabilen ve hatta tedavinin kesilmesine yol açabilen yan etkileridir. DA’lar için kesilme oranlarının bire bir karşılaştıran çalışmlar ise çok sınırlıdır. Parkinson hastalığı $(\mathrm{PH})$ olan hastalarda pramipeksol ve ropinirol tedavilerinin kesilme sıklığını ve özelliklerini araștırmayı ve bunların kesilmesine ilişkin risk faktörlerini belirlemeyi amaçladık. DA tedavisi (pramipeksol veya ropinirol) uygulanan 329 hastanın verileri geriye dönük olarak belirlendi. İki DA grubu arasında demografik özellikler, hastalık süresi, levodopa eșdeğer dozu, dopamin agonist dozu, ilgili yan etkiler, DA tedavi süresi ve Hoehn ve Yahr (HY) ölçek skorları karşılaştırıldı. Olumsuz etkilere bağlı olarak DA’lerin kesilme oranı\% 51,6 idi. Psikiyatrik yan etkiler (\%14,3) tedaviyi bırakmanın en sık nedeniyken, dürtü kontrol bozuklukları (DKB) ve pedal ödemi diğer öne çlkan nedenlerdi. Pramipeksol grubunda HY evre 2 ve 3 olan hastalarda tedaviyi bırakma oranı daha yüksekti, yine başlangıç yaşı ve hastalık süresi arttıkça bıraka oranı artmaktaydı . Ropinirol grubunda DKB daha yüksek prevalansa sahipti. Gündüz uykululuk, kabızlık ve baş ağrısı gibi sık görülen yan etkiler DA’lerin kesilmesinin nedeni olarak bulunmadı; daha ziyade psikoz, dürtü kontrol bozukluğu ve pedal ödemi nedeniyle hastalar bu tedavileri çoğunlukla bırakmıștı. Hastaların yarısından fazlasında yan etkilerin tedavinin kesilmesine yol açması dikkat çekicidir.

Anahtar Kelimeler: Tedavi kesilmesi, dopamin agonistleri, Parkinson hastalığı, yan etki 


\section{Introduction}

Dopamine agonists (DAs) have been proven to effectively treat the motor and non-motor symptoms of Parkinson's disease (PD). These molecules are the first-line treatment for relatively early-onset ( $<65$ years) PD cases without dementia, since they delay levodoparelated motor complications [1]. The greatest difficulty in the use of DAs is their adverse effects which may outweigh their efficacy or even be disabling. The most common side effects are nausea, hypotension (orthostatic), impulse control disorders, daytime sleepiness, psychosis, and pedal edema, which can develop in any stage of the treatment and lead to discontinuation [2]. However, there are only a few studies in the literature that provide a head-to-head comparison of the discontinuation rates of DAs [3,4]. In addition, the differences between DAs with regard to the frequency and severity of their adverse effects are yet to be fully elucidated. Therefore, our study primarily aimed to investigate the prevalence and characteristics of the discontinuation of pramipexole and ropinirole treatments in patients with $\mathrm{PD}$. The secondary aim of our study was to determine the risk factors related to the discontinuation of these treatments.

\section{Material and Methods}

In this study, the data of 596 patients with PD were retrospectively evaluated from the outpatient records of the movement disorders unit of the neurology department of Osmangazi University Medical Faculty between 2008 and 2018. The PD diagnosis was based on the United Kingdom Parkinson's Disease Brain Bank Criteria [5]. Patients with a diagnosis of vascular parkinsonism and those with drug-induced or atypical parkinsonism were excluded. Patients without any DA treatment and/or DA treatment history other than ropinirole and pramipexol were also excluded. Of the 596 patients, 329 were determined to have undergone DA treatment with pramipexole extended release or ropinirole.
The demographic data, disease duration, levodopa equivalent dose (LEDD), dopamine agonist dosage, related adverse effects, duration of DA treatment, and the Hoehn and Yahr (HY) scale scores of these patients when experiencing side effects were recorded from the hospital database, and the data were compared between the ropinirole and pramipexole treatment groups.

\section{Ethical aspects}

This study was approved by the local ethics committee of Osmangazi University (protocol number: 25403353-050.99-E46792).

\section{Statistical analysis}

The Shapiro-Wilk normality test was applied for continuous variables. Variables with a normal distribution were analyzed with the independent-samples t-test and expressed as mean \pm standard deviation. For variables without a normal distribution, the MannWhitney U test was applied, and the data were expressed as median (25-75\%) values. The chi-square test was conducted for the analysis of categorical variables expressed as frequency and percentages. Spearman's correlation test was used to test the relationship between variables. SPSS Statistics v. 22.0 (IBM, SPSS Inc., Chicago, IL) was used for the risk factor analysis. A p value of $<0.05$ was considered statistically significant.

\section{Results}

The descriptive data of the patients who underwent DAs treatment is provided in Table 1. There were no statistical differences between the two DA groups in terms of age, sex, H\&Y score, treatment duration, and LEDD, and only disease duration was significantly longer in the pramipexole group $(p=0.005)$. These results indicated that the data of the two groups were similar. 
Table 1. Demographic data of the patients

\begin{tabular}{|c|c|c|c|c|}
\hline & $\begin{array}{c}\text { Ropinirole group } \\
(n=80)\end{array}$ & $\begin{array}{l}\text { Pramipexole } \\
\text { group }(n=249)\end{array}$ & $p$ value & Total $(n=329)$ \\
\hline \multicolumn{5}{|l|}{ Age years } \\
\hline Mean \pm SD & $\begin{array}{l}63.6 \pm 9.4 \\
62(37-88)\end{array}$ & $\begin{array}{c}64,1 \pm 10.3 \\
64(35-90)\end{array}$ & $0.81^{\mathrm{a}}$ & $\begin{array}{l}64 \pm 10.1 \\
64(35-90)\end{array}$ \\
\hline $\operatorname{Sex}(n-\%)$ & & & & \\
\hline Male & $41(51.2)$ & $131(52.6)$ & $0.90^{\mathrm{b}}$ & $172(52.3)$ \\
\hline Female & $39(48.8)$ & $118(47.4)$ & & $157(47.7)$ \\
\hline \multicolumn{5}{|l|}{ Hoehn \& Yahr stage (n-\%) } \\
\hline 1 & $16(20)$ & $57(22.9)$ & & $72(22.2)$ \\
\hline 2 & $25(31.3)$ & $95(38.2)$ & $0.36^{\mathrm{b}}$ & $120(36.5)$ \\
\hline 3 & $29(37.3)$ & $75(30.1)$ & & $104(31.6)$ \\
\hline 4 & $10(12.5)$ & $19(7.6)$ & & $29(8.8)$ \\
\hline 5 & - & $3(1.2)$ & & $3(0.9)$ \\
\hline \multicolumn{5}{|l|}{ Disease duration, years Mean \pm} \\
\hline SD & $10.36 \pm 5.5$ & $8.65 \pm 5.45$ & $0.01^{\mathrm{c}}$ & $9.07 \pm 5.51$ \\
\hline Median (min-max) & $9(2-33)$ & $7(1-31)$ & & $8(1-33)$ \\
\hline \multicolumn{5}{|l|}{ Treatment duration, years } \\
\hline Mean \pm SD & $5.4 \pm 3.2$ & $5.5 \pm 0.4$ & $0.19^{\mathrm{c}}$ & $5.1 \pm 3.47$ \\
\hline Median (min-max) & $5(0.3-12)$ & $4(0.3-15)$ & & $5(0.3-15)$ \\
\hline LEDD mean \pm SD & $1103.0 \pm 49.1$ & $976.6 \pm 523.5$ & $0.06^{\mathrm{a}}$ & $1007.4 \pm 517.9$ \\
\hline DA-LEDD mean \pm SD & $317.3 \pm 158.0$ & $309.6 \pm 125.6$ & $0.659^{\mathrm{a}}$ & $311.0 \pm 191.9$ \\
\hline
\end{tabular}

The rate of the discontinuation of the DAs due to adverse effects was $51.6 \%(169 / 329)$. When all the patients were evaluated $(n=329)$, psychiatric side effects were the most common reason for discontinuation, seen in a total of 47 patients (14.3\%). A total of 39 $(11.9 \%)$ patients discontinued treatment due to impulse control disorder (ICD), 33 (10.0\%) due to pedal edema, $18(5.5 \%)$ due to deep brain stimulation treatment (DBS), $12(3.6 \%)$ due to dementia, $10(3.0 \%)$ due to headache/somnolence, and nine $(2.7 \%)$ for other reasons.

When the ropinirole- and pramipexole-treated patient groups were compared, there was no statistically significant difference according to the discontinuation rate when all the reasons for discontinuation were evaluated together ( $\mathrm{p}$ $>0.05)$. Forty-eight $(59.2 \%)$ of the 80 patients using ropinirole and $121(48.5 \%)$ of the 249 patients using pramipexole discontinued treatment due to adverse effects or DBS treatment. When evaluated separately, the rate of discontinuation due to ICD was significantly greater in the ropinirole group compared to the pramipexole group $(\mathrm{p}=$ 0.049 ). There were no statistically significant differences between the groups in terms of psychiatric side effects (hallucinations, delusions, and psychosis), headache, pedal edema, dementia, discontinuation due to DBS or other reasons $(p>0.05)$. The prevalence of each adverse effect and their comparison between the groups are presented in Table 2 .

Table 2. Reasons for discontinuation in the ropinirole and pramipexole groups

\begin{tabular}{|c|c|c|c|}
\hline Side Effect & Ropinirole (n, \%) & Pramipexole (n, \%) & $p^{* *}$ \\
\hline \multirow{2}{*}{ Drug discontinued } & $48(59.2)$ & $121(48.5)$ & 0.08 \\
\hline & & & $\mathrm{P}$ \\
\hline $\begin{array}{l}\text { Psychiatric side effects } \\
\text { (hallucinations, delusions, and } \\
\text { psychosis) }\end{array}$ & $13(27.1)$ & $34(25.3)$ & $0.87^{* *}$ \\
\hline Headache/somnolence & $1(2.1)$ & $9(7.4)$ & $0.18^{* *}$ \\
\hline
\end{tabular}




\begin{tabular}{lccc}
\hline Pedal edema & $7(14.6)$ & $26(21.5)$ & $0.31^{* *}$ \\
Dementia & $2(4.2)$ & $10(8.3)$ & $0.34^{*}$ \\
\hline Impulse control disorder & $\mathbf{1 6}(\mathbf{3 3 . 3})$ & $\mathbf{2 2 ( 1 8 . 2 )}$ & $\mathbf{0 . 0 1}^{*}$ \\
\hline Deep brain stimulation & $4(8.3)$ & $15(12.4)$ & $0.59^{*}$ \\
\hline Other & $5(10.4)$ & $5(4.1)$ & $0.15^{*}$ \\
$p^{*=0.261}$ & & & \\
$*$ Fisher's exact Test & & & \\
$* *$ Chi-square test & & & \\
\hline
\end{tabular}

The discontinuation rate was found to be higher in patients with HY stage 2 and 3 in the pramipexole group and those with increased age at disease onset and increased disease duration $(p<0.05)$. In contrast, in the ropinirole group, there was no significant difference in discontinuation frequency according to the HY stages.

\section{Risk factors of discontinuation}

In the ropinirole group, $11.9 \%$ of the patients discontinued treatment due to ICD, which was higher than observed in the pramipexole group. The odds ratio of the ICD risk was 2.58 times higher in the ropinirole group.

According to the results of the logistic regression analysis, the prevalence of ICD was 2.5 times greater in the males compared to the females for the whole sample, and 5.5 times greater in the ropinirole group. Early onset of the disease, disease duration, treatment duration, and patient age were not found to be risk factors. The descriptive data of the patients who discontinued DA therapy are summarized in Table 3.

Table 3. Demographic data of the patients that discontinued dopamine antagonist treatment

\begin{tabular}{lccc}
\hline & $\begin{array}{c}\text { Ropinirole group } \\
(\boldsymbol{n}=\mathbf{4 8})\end{array}$ & $\begin{array}{c}\text { Pramipexole } \\
\text { group }(\boldsymbol{n}=\mathbf{1 2 1})\end{array}$ & Total $(\boldsymbol{n}=\mathbf{3 2 9})$ \\
\hline Age -years & $64.6 \pm 10.1$ & $67.2 \pm 10.3$ & $66.4 \pm 10.3$ \\
Mean \pm SD & $63(37-88)$ & $68(36-90)$ & $66(36-90)$ \\
Median (min-max) & & & \\
Sex (n-\%) & & & \\
Male & $27(56.3)$ & $58(47.2)$ & $85(50.3)$ \\
Female & $21(43.8)$ & $63(52.1)$ & 1 \\
Disease duration, years (mean \pm & $11.2 \pm 6.1$ & $9.9 \pm 5.3$ & $0.3 \pm 5.5$ \\
SD) & $10(2.33)$ & $9(2-26)$ & $9(2-33)$ \\
Median (min max) & $5.3 \pm 3.8$ & $5.415 \pm 3.5$ & $5.4 \pm 3.6$ \\
Treatment duration years, & $4.5(0.3-12)$ & $5(3-15)$ & \\
Mean \pm SD & $1092.7 \pm 482.8$ & $1020.1 \pm 549.2$ & $1040.9 \pm 530.7$ \\
Median (min-max) & & & \\
LEDD & & & \\
Mean \pm SD & $289.6 \pm 156.6$ & $276.7 \pm 129.8$ & $280.4 \pm 37.6$ \\
DA-LEDD & & & \\
Mean \pm SD &
\end{tabular}

$S D$, standard deviation; LEDD, levodopa equivalent daily dose; DA-LEDD, dopamine agonist levodopa equivalent daily dose

While age and disease duration were not risk factors for discontinuation in the ropinirole group, they were found to be risk factors in the pramipexole group $(\mathrm{p}<0.001$ and $\mathrm{p}=$ 0.001 , respectively). The comparison of the risk factors of discontinuation for both groups is summarized in Table 4. 
Table 4. Association between risk factors and drug discontinuation in ropinirole and pramipexole groups

\begin{tabular}{lll}
\hline & $\begin{array}{l}\text { Pramipexol } \\
\text { p values }\end{array}$ & $\begin{array}{l}\text { Ropinirole } \\
\text { p values }\end{array}$ \\
\hline Age & $<0.001$ & $0,273^{*}$ \\
Gender & $0.37^{* *}$ & $0.151^{* *}$ \\
Disease duration & $0.001^{*}$ & $0.096^{*}$ \\
Treatment duration & $0.078^{*}$ & $0.732^{*}$ \\
Levodopa equivalent daily dose & $0.205^{*}$ & $0.820^{*}$ \\
& & \\
$*$ Independent-samples t-test & & \\
$* *$ Pearson's chi-Square test & & \\
Statistically significant at $\mathbf{p}<\mathbf{0 . 0 5}$ & \\
\hline Dopamine agonists-levodopa equivalent daily dose: $0.000^{*} \mathrm{p} / \mathrm{r}$
\end{tabular}

\section{Discussion}

Although the side effects of DAs are well defined, the frequency of drug discontinuation due to side effects has not been sufficiently discussed. This study focused on the frequency and causes of DA discontinuation. The discontinuation rate was determined to be $59.2 \%$ for ropinirole and $48.5 \%$ for pramipexole. In retrospective studies with a follow-up of up to three years, the rate of discontinuation was reported to range from 7 to $69 \%$ for ropinirole and 0 to $60 \%$ for pramipexole, which was consistent with our results $[3,4]$.

Multicenter randomized, double-blind, controlled studies investigating the efficacy and safety and discontinuation reasons for pramipexole have reported a discontinuation rate of $4.8-12 \%$ due to adverse effects. However, these studies did not indicate the variety of adverse effects that resulted in discontinuation and evaluated data from a maximum of 33-week follow-up period [611]. The rate of discontinuation in our study was similar to previous retrospective studies, but our results were markedly higher than randomized controlled trials (RCTs). The follow-up periods of RCTs were much shorter compared to our study. For this reason, it may not be appropriate to compare them with our findings. Another possible reason is that increasing awareness of the adverse effects of DAs in recent years may have led patients and doctors to attach more importance to this subject and make a decision to discontinue these treatments.
In our study, psychiatric side effects and ICD were the most common reason for the discontinuation of DAs, which is also consistent with the literature [12]. In PD patients using dopamine agonists, psychiatric side effects (hallucinations, delusions, and psychosis) develop secondary to the activation of the dopaminergic receptors of the mesocorticolimbic pathway [3]. In RCTs, the prevalence of psychiatric side effects was 4$10.7 \%$ for pramipexole and $7 \%$ for ropinirole [6,10,11,13-16]. Both head-to-head comparison and placebo-controlled studies of DAs reported increased risk of hallucinations in pramipexole rather than ropinirole [17-19]. We did not come across a study in the literature that reported discontinuation due to psychosis; therefore, we were not able to conduct a direct comparison. In our study, the rate of discontinuation due to psychiatric side effects was $14.3 \%$ for the whole study group. Furthermore, psychiatric side effects constituted $27.8 \%$ of all reasons for discontinuation.

In studies on PD patients treated with DAs, the ICD prevalence have been reported in a wide range of $8-39 \%[1,14,20,21]$. In our study, ICD was assessed with the Questionnaire for Impulsive Compulsive Disorders in Parkinson's Disease, and the ICD prevalence among all patients was $10.9 \%$, consistent with the literature. Although the incidence of ICD has been reported in previous studies, there is only one study that evaluated drug discontinuation due to ICD, 
which reported this rate as $2.6 \%$ (31). In our study, treatment was conservatively discontinued in all patients who developed $\operatorname{ICD}(\mathrm{n}=36)$, which was the second most common reason for discontinuation, constituting $21.3 \%$ of all discontinuation cases.

When the discontinuation rate associated with ICD was evaluated separately for the ropinirole and pramipexole groups, the discontinuation rate was determined as $17 \%$ for ropinirole and $33,6 \%$ for pramipexole. In previous studies, the ICD prevalence has been reported to be $17.8-43.1 \%$ for pramipexole and $15.5-42 \%$ for the ropinirole group $[1,14]$; however, the authors did not indicate whether or not treatment was discontinued in these patients. Early onset of disease, being single, having a family history of gambling, and smoking were reported as risk factors [14].

A new meta-analysis conducted in 2018 by Grall-Bronnec et al. examining 90 recent studies reported that male gender, young age, history of psychiatric disorder, long disease duration, drug dosage, and early age of onset were risk factors for the development of ICD [22]. In our study, the discontinuation rate due to ICD was significantly greater in the ropinirole group compared to the pramipexole group $(\mathrm{p}=0.049)$. Additionally, our results showed that ropinirole use resulted in 2.58 times greater risk of ICD development compared to pramipexole. These results are not in agreement with the reports in the literature indicating that pramipexole has higher ICD prevalence [1,23-25]. This may be due to the differences in the number of patients in our two groups (pramipexole: 249; ropinirole: 80 ) or our follow-up period being longer than in previous studies.

In the literature, the pedal edema prevalence has been reported as $7.9-22.5 \%$ in patients using DAs (35-38). Consistent with the

\section{REFERENCES}

1. Garcia-Ruiz PJ, Martinez Castrillo JC, AlonsoCanovas A, Herranz Barcenas A, Vela L, Sanchez Alonso P, Mata M, Olmedilla Gonzalez N, Mahillo Fernandez I. Impulse control disorder in patients with Parkinson's disease under dopamine literature, in our study, the prevalence of pedal edema was $10.4 \%$ in the pramipexole group and $8.75 \%$ in the ropinirole group. In previous studies, $5.7-37 \%$ of patients that developed pedal edema were seen to have discontinued DAs $[9,26]$. The prevalence of pedal edema may have been higher since the additional diseases of the patients were not recorded, and although the drugs were discontinued after excluding other causes of pedal edema in our clinic, this was undocumented.

\section{Limitations}

The most important limitation of our study was that the reasons for discontinuation were evaluated retrospectively and only the data on discontinuation rates were examined without the further assessment of patients that chose to cope with side effects by decreasing the DA dose. Also, The UPDRS scores of the patients were not mentioned in the study due to deficiencies in the medical records. The difference in the number of the patients between the two groups is another limitation for our study.

\section{Conclusion}

Adverse effects that developed due to the use of DAs in our patient group were consistent with the literature. Common side effects such as daytime sleepiness, constipation, and headache were not reasons for discontinuation; rather, psychosis, impulse control disorder, and pedal edema resulted in the discontinuation of DAs. It is noteworthy that adverse effects led to the discontinuation of treatment in over half of the patients. Increasing awareness of these symptoms and conducting research during follow-up can be helpful in early detection and management of side effects. Further prospective randomized controlled studies on the reasons for DA discontinuation and related risk factors will be beneficial. 
Nieuwboer A, Odin P, Poewe W, Rascol O, Sampaio C, Schüpbach M, Tolosa E, Trenkwalder C, Schapira A, Berardelli A, Oertel WH. Summary of the recommendations of the EFNS/MDS-ES review on therapeutic management of Parkinson's disease. Eur J Neurol. 2013;20:5-15.

3. Borovac JA. Side effects of a dopamine agonist therapy for Parkinson's disease: a mini-review of clinical pharmacology. Yale $J$ Biol Med. $2016 ; 24 ; 89: 37-47$.

4. Alonso Cánovas A, Luquin Piudo R, García RuizEspiga P, Burguera JA, Campos Arillo V, Castro A, Linazasoro G, López Del Val J, Vela L, Martínez Castrillo JC. Dopaminergic agonists in Parkinson's disease. Neurologia. 2014;29:230-41.

5. Gibb WR, Lees AJ. The relevance of the Lewy body to the pathogenesis of idiopathic Parkinson's disease. $J$ Neurol Neurosurg Psychiatry. 1988;51:745-52.

6. Schapira AH, Barone P, Hauser RA, Mizuno Y, Rascol O, Busse M, Salin L, Juhel N, Poewe W; Pramipexole ER Studies Group. Extended-release pramipexole in advanced Parkinson disease: a randomized controlled trial. Neurology. 2011; 23;77:767-74.

7. Poewe W, Rascol O, Barone P, Hauser RA, Mizuno Y, Haaksma M, Salin L, Juhel N, Schapira AH; Pramipexole ER Studies Group. Extended-release pramipexole in early Parkinson disease: a 33-week randomized controlled trial. Neurology. 2011; 23;77:759-66.

8. Hauser RA, Schapira AH, Barone P, Mizuno Y, Rascol O, Busse M, Debieuvre C, Fraessdorf M, Poewe W; Pramipexole ER Studies Group. Longterm safety and sustained efficacy of extendedrelease pramipexole in early and advanced Parkinson's disease. Eur J Neurol. 2014 ;21:73643.

9. Schapira AH, McDermott MP, Barone P, Comella CL, Albrecht S, Hsu HH, Massey DH, Mizuno Y, Poewe W, Rascol O, Marek K. Pramipexole in patients with early Parkinson's disease (PROUD): a randomised delayed-start trial. Lancet Neurol. 2013;12:747-55.

10. Mizuno Y, Yamamoto M, Kuno S, Hasegawa K, Hattori N, Kagimura T, Sarashina A, Rascol O, Schapira AH, Barone P, Hauser RA, Poewe W; Pramipexole ER Study Group. Efficacy and safety of extended- versus immediate-release pramipexole in Japanese patients with advanced and L-dopa-undertreated Parkinson disease: a double-blind, randomized trial. Clin Neuropharmacol. 2012;35:174-81.

11. Stocchi F, Giorgi L, Hunter B, Schapira AH. prepared: Comparison of prolonged and immediate release ropinirole in advanced Parkinson's disease. Mov Disord. 2011;26:125965.

12. Chaudhuri KR, Todorova A, Nirenberg MJ, Parry M, Martin A, Martinez-Martin P, Rizos A, Henriksen T, Jost W, Storch A, Ebersbach G, Reichmann H, Odin P, Antonini A. A Pilot Prospective, Multicenter Observational Study of Dopamine Agonist Withdrawal Syndrome in Parkinson's Disease. Mov Disord Clin Pract. 2015; 16;2:170-174.
13. [13] Molina JA, Sáinz-Artiga MJ, Fraile A, Jiménez-Jiménez FJ, Villanueva C, Ortí-Pareja M, Bermejo F. Pathologic gambling in Parkinson's disease: a behavioral manifestation of pharmacologic treatment? Mov Disord. 2000;15:869-72.

14. Weintraub D, Siderowf AD, Potenza MN, Goveas J, Morales KH, Duda JE, Moberg PJ, Stern MB. Association of dopamine agonist use with impulse control disorders in Parkinson disease. Arch Neurol. 2006;63:969-73.

15. [15] Ambermoon P, Carter A, Hall WD, Dissanayaka NN, O'Sullivan JD. Impulse control disorders in patients with Parkinson's disease receiving dopamine replacement therapy: evidence and implications for the addictions field. Addiction. 2011;106:283-93.

16. Stocchi F, Radicati FG, Torti M. Drug safety evaluation of ropinirole prolonged release. Expert Opin Drug Saf. 2014;13:383-9.

17. Etminan M, Gill S, Samii A. Comparison of the risk of adverse events with pramipexole and ropinirole in patients with Parkinson's disease: a meta-analysis. Drug Saf. 2003;26:439-44.

18. Pondal M, Marras C, Miyasaki J, Moro E, Armstrong MJ, Strafella AP, Shah BB, Fox S, Prashanth LK, Phielipp N, Lang AE. Clinical features of dopamine agonist withdrawal syndrome in a movement disorders clinic. $J$ Neurol Neurosurg Psychiatry. 2013;84:130-5.

19. Hollingworth SA, McGuire TM, Pache D, Eadie MJ. Dopamine Agonists: Time Pattern of Adverse Effects Reporting in Australia. Drugs Real World Outcomes. 2015;2:199-203.

20. [20] Ceravolo R, Frosini D, Rossi C, Bonuccelli U. Impulse control disorders in Parkinson's disease: definition, epidemiology, risk factors, neurobiology and management. Parkinsonism Relat Disord. 2009;15 Suppl 4:S111-5.

21. Voon V, Sohr M, Lang AE, Potenza MN, Siderowf AD, Whetteckey J, Weintraub D, Wunderlich GR, Stacy M. Impulse control disorders in Parkinson disease: a multicenter case-control study. Ann Neurol. 2011;69:986-96.

22. Grall-Bronnec M, Victorri-Vigneau C, Donnio Y, Leboucher J, Rousselet M, Thiabaud E, Zreika N, Derkinderen P, Challet-Bouju G. Dopamine Agonists and Impulse Control Disorders: A Complex Association. Drug Saf. 2018;41:19-75.

23. Moore TJ, Glenmullen J, Mattison DR. Reports of pathological gambling, hypersexuality, and compulsive shopping associated with dopamine receptor agonist drugs. JAMA Intern Med. 2014;174:1930-3.

24. Joutsa J, Martikainen K, Vahlberg T, Voon V, Kaasinen V. Impulse control disorders and depression in Finnish patients with Parkinson's disease. Parkinsonism Relat Disord. 2012;18:15560 .

25. Bharmal A, Lu C, Quickfall J, Crockford D, Suchowersky O. Outcomes of patients with Parkinson disease and pathological gambling. Can J Neurol Sci. 2010;37:473-7.

26. Tan EK, Ondo W. Clinical characteristics of pramipexole-induced peripheral edema. Arch Neurol. 2000;57:729-32. 